BIO-CONS, Jurnal Biologi \& Konservasi

Volume 3 No. 2, Desember 2021

p-ISSN : 2620-3510, e-ISSN: 2620-3529

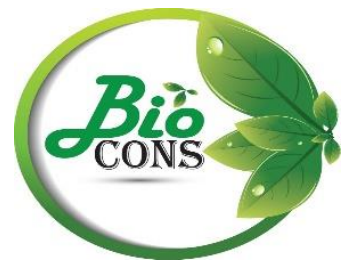

\title{
PEMANFAATAN MEDIA LINGKUNGAN UNTUK MENINGKATKAN KEMAMPUAN BERCERITA PADA ANAK USIA DINI
}

\section{UTILIZATION OF ENVIRONMENTAL MEDIA TO IMPROVE STORYING ABILITY IN EARLY CHILDREN}

\author{
Waris*, Supatmi \\ *) Corresponding Author \\ Universitas PGRI Argopuro Jember \\ Email: drwaris668@gmail.com
}

\begin{abstract}
ABSTRAK
Peran pendidik (orang tua, guru, dan orang dewasa lain) sangat diperlukan dalam upaya pengembangan potensi anak usia 4-6 tahun. Perkembangan bahasa anak usia dini memang masih jauh dari sempurna, namun demikian potensinya dapat distimulasi lewat komunikasi yang aktif dengan menggunakan bahasa yang baik dan benar. Kualitas bahasa yang digunakan orang-orang yang dekat dengan anak akan mempengaruhi keterampilan bercerita pada anak. Pada proses pembelajaran, seorang guru sangat dituntut untuk selalu berinovasi dalam memilih dan menggunakan media pembelajaran, khususnya yang dapat meningkatkan kemampuan bercerita pada anak usia dini. Penelitian ini bertujuan untuk meningkatkan kemampuan bercerita pada anak usia dini dengan mengimplementasikan media lingkungan. Subjek penelitian ini adalah siswa kelompok A di TK Al Furqon Maesan Bondowoso yang berjumlah 33 siswa. Penelitian ini merupakan penelitian tindakan kelas yang dilakukan dalam 2 siklus, masing-masing siklus terdiri dari 4 tahap yaitu: perencanaan, tindakan/pelaksanaan, observasi, dan evaluasi/refleksi. Berdasarkan hasil observasi dan analisis hasil observasi pada siklus I diperoleh data bahwa 22 siswa $(63,6 \%)$ masih belum bisa bercerita dengan baik dan 12 siswa $(36,4 \%)$ sudah mampu bercerita dengan baik. Data pada siklus I belum sesuai dengan KKM (>80\%), sehingga dilanjutkan ke siklus II. Berdasarkan hasil observasi dan analisis hasil observasi pada siklus II diperoleh bahwa $4(13 \%)$ siswa masih belum bisa bercerita dengan baik dan 29 siswa (87\%) sudah mampu bercerita dengan baik. Berdasarkan hasil tersebut dapat disimpulkan bahwa implementasi media lingkungan dapat meningkatkan kemampuan bercerita pada anak usia dini.
\end{abstract}

Kata Kunci : Kemampuan Bercerita, Media Lingkungan. 


\begin{abstract}
The role of educators (parents, teachers, and other adults) is indispensable in efforts to develop the potential of children aged 4-6 years. The development of early childhood language is still far from perfect, however, its potential can be stimulated through active communication using good and correct language. The quality of the language used by people who are close to the child will affect the storytelling skills of the child. In the learning process, a teacher is highly required to always innovate in choosing and using learning media, especially those that can improve storytelling skills in early childhood. This study aims to improve storytelling skills in early childhood by implementing environmental media. The subjects of this study were students of group A in TK Al Furqon Maesan Bondowoso, totaling 33 students. This research is a classroom action research conducted in 2 cycles, each cycle consists of 4 stages, namely: planning, action/implementation, observation, and evaluation/reflection. Based on the results of observations and analysis of observations in the first cycle, it was found that 22 students $(63.6 \%)$ still could not tell stories well and 12 students (36.4\%) were able to tell stories well. The data in the first cycle is not in accordance with the KKM (>80\%), so it is continued to the second cycle. Based on the results of observations and analysis of observations in cycle II, it was found that $4(13 \%)$ students still could not tell stories well and 29 students $(87 \%)$ were able to tell stories well. Based on these results, it can be concluded that the implementation of environmental media can improve storytelling skills in early childhood.
\end{abstract}

Keywords: Storytelling Skills, Environmental Media.

\title{
PENDAHULUAN
}

Anak usia 4-6 tahun secara terminologi disebut sebagai anak usia prasekolah (UndangUndang RI Nomor 20 tahun 2003). Perkembangan otak anak pada masa ini mengalami peningkatan dari $50 \%$ menjadi $80 \%$. Hal ini menunjukkan pentingnya upaya pengembangan seluruh potensi anak usia prasekolah, untuk itu peran pendidik (orang tua, guru, dan orang dewasa lain) sangat diperlukan dalam upaya pengembangan potensi anak 4-6 tahun. Pada usia 4-6 tahun anak mengalami masa 2 peka, dimana anak mulai sensitif untuk menerima berbagai upaya pengembangan seluruh potensi anak. Masa peka adalah masa terjadinya pematangan fungsi-fungsi fisik dan psikis yang siap merespon simulasi yang diberikan oleh lingkungan (Musfiroh, 2005). Oleh sebab itu, dibutuhkan kondisi dan simulasi yang sesuai dengan kebutuhan anak agar pertumbuhan dan perkembangan anak tercapai secara optimal.

Perkembangan bahasa anak usia dini memang masih jauh dari sempurna, namun demikian potensinya dapat dirangsang lewat komunikasi yang aktif dengan menggunakan bahasa yang baik dan benar. Keterampilan bercerita pada anak akan dipengaruhi oleh kualitas bahasa yang digunakan orang-orang yang dekat dengan anak itu sendiri (Sudjiono, 2009).

Guru merupakan salah seorang yang dapat mempengaruhi perkembangan bercerita pada anak. Guru PAUD harus dapat mengupayakan berbagai strategi pembelajaran yang dapat mengembangkan kemampuan bercerita pada anak. Pada proses pembelajaran guru dapat memilih suatu media pembelajaran yang tepat, sederhana dan mudah didapat, seperti 
memanfaatkan lingkungan sebagai media untuk merangsang anak dalam berlatih bercerita. Tetapi, pada kenyataannya masih jarang guru yang memanfaatkan media tersebut.

Berdasarkan latar belakang tersebut, maka Peneliti tertarik untuk memanfaatkan media lingkungan untuk meningkatkan kemampuan bercerita pada anak. Penelitian ini bertujuan meningkatkan kemampuan bercerita anak melalui pemanfaatan media lingkungan yang aktual. Lingkungan diasumsikan memiliki keefektifan dalam meningkatkan kemampuan bercerita pada anak. Kegiatan pembelajaran yang konstekstual dengan memanfaatkan media lingkungan akan menjadi lebih menarik, sehingga anak menjadi bersemangat dalam mengikuti pembelajaran. Sudjana dan Rivai (2014) menyatakan bahwa dalam teknik penggunaan media lingkungan, siswa dituntut untuk menghayati objek tertentu dengan merekam apa yang dialami, dilihat, didengar, dan dirasakan selama kegiatan berlangsung. Sedang menurut Hamalik (1989) mengatakan bahwa komunikasi dan interaksi antara guru dengan siswa akan terjadi dengan baik bila menggunakan metode dan media yang tepat.

\section{METODE PENELITIAN}

Penelitian ini dilakukan pada siswa kelompok A di Taman Kanak-kanak Al Furqon Maesan Bondowoso, Tahun Pelajaran 2020-2021. Subjek penelitian ini adalah siswa kelompok A TK Al Furqon yang berjumlah 33 siswa, yang terdiri dari 18 siswa laki-laki dan 15 siswa perempuan.

Prosedur penelitian dilakukan dalam 4 tahapan, yaitu: tahap 1 adalah perencanaan, tahap 2 pelaksanaan, tahap 3 observasi dan tahap 4 refleksi. Keempat tahapan dilaksanakan secara siklus sebagaimana tampak pada bagan sebagai berikut: 


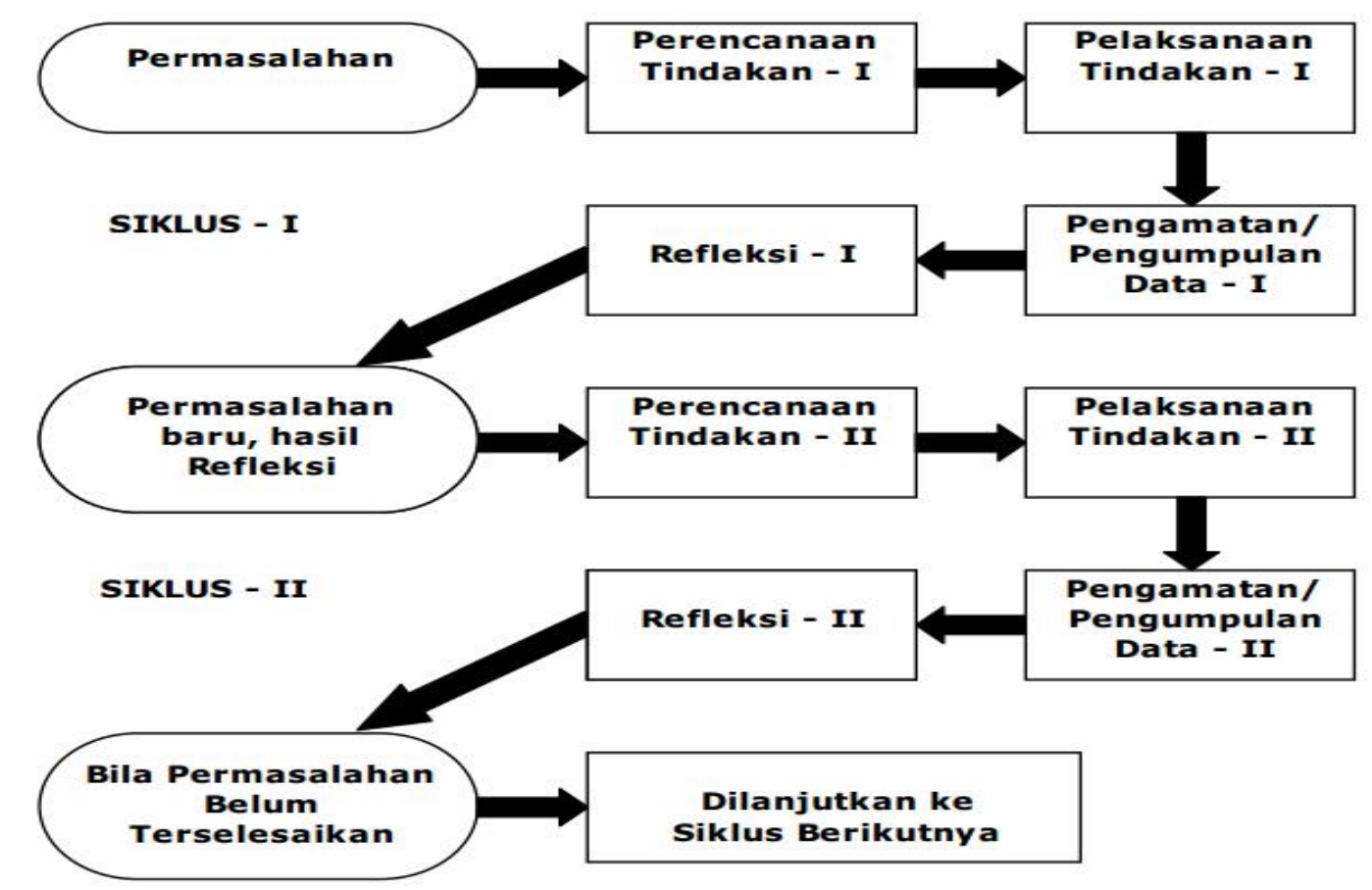

Gambar 1. Bagan Siklus Prosedur Penelitian Tindakan Kelas

Sumber: https://lpmpjogja.kemdikbud.go.id/penelitian-tindakan-kelas-ptk, (2015)

Pada tahap perencanaan dilakukan penyusunan perangkat pembelajaran yang meliputi penyusunan RPPH, dan lembar observasi. Tahap pelaksanaan merupakan tahap dilaksanakannya proses pembelajaran sesuai dengan yang telah direncanakan. Tahap observasi merupakan tahap pengamatan pelaksanaan pembelajaran dari guru model dan aktivitas siswa selama proses pembelajaran berlangsung. Pengamatan dilakukan oleh observer. Tahap refleksi merupakan tahap diskusi terhadap hasil observasi dan tindaklanjut perbaikan perencanaan untuk pelaksanaan pembelajaran berikutnya.

Analisis data dilakukan terhadap hasil observasi dan evaluasi kemampuan bercerita pada anak. Analisis data dilakukan secara deskriptif kualitatif dengan kriteria belum baik dalam bercerita dan sudah baik dalam bercerita.

\section{HASIL DAN PEMBAHASAN}

Penelitian ini dilaksanakan dalam 2 siklus, setiap siklus dilakukan perlakukan yang berbeda dengan perubahan yang dicapai seperti yang telah direncanakan dalam faktor yang ingin diteliti. Hasil penelitian setiap siklusnya adalah sebagai berikut:

\section{Siklus I}

a. Perencanaan ( Planning )

- Menyiapkan perangkat pembelajaran terdiri atas penyusunan skenario pembelajaran yang tertuang dalam Rencana Program Pembelajaran Harian (RPPH); 
- Menyiapkan berbagai perlengkapan untuk membawa siswa ke halaman sekolah untuk mengamati berbagai tanaman yang ada dihalaman sekolah;

- Membuat instrumen observasi/penilaian yang digunakan dalam siklus I

\section{b. Pelaksanaan Tindakan ( Action )}

- Kegiatan awal pembelajaran, guru menyampaikan pendahuluan meliputi penyampaian tujuan pembelajaran, yaitu anak mampu mendengarkan guru atau teman berbicara dan anak mampu menceritakan kembali hasil kegiatannya dengan baik.

- Kegiatan inti pembelajaran, guru menjelaskan kegiatan pembelajaran dengan menggunakan media lingkungan tanaman sambil mempraktekkan bagaimana cara menanam bunga mulai langkah awal sampai akhir, guru meminta kepada anak untuk mempraktekkan bagaimana cara menanam bunga mulai dari awal sampai akhir secara bergantian dengan siswa yang lain.

- Kegiatan akhir pembelajaran, guru menyimpulkan hasil pembelajaran dan melakukan evaluasi dengan menyuruh anak untuk menceritakan kembali kegiatan yang telah dilakukan secara bergiliran.

\section{c. Observasi}

Pengumpulan data pada penelitian digunakan pengamatan sistematis yaitu observasi yang dilakukan dengan menggunakan pedoman lembar observasi sebagai instrumen pengamatan. Hasil observasi siklus I menunjukan bahwa belum semua anak berantusias untuk mengikuti pembelajaran. Dari 33 anak ternyata yang mempunyai kemampuan bercerita sesuai dengan standar ketuntasan belajar yang mencapai $>80 \%$ teranyata masih rendah yaitu sebanyak $36.4 \%$.

e. Refleksi

Berdasarkan hasil pelaksanaan tindakan dan observasi kemampuan bercerita melalui pemanfaatan media lingkungan pada siklus I dapat diketahui bahwa perlu diadakan beberapa perbaikan meliputi peningkatan kualitas aktivitas guru, aktivitas anak dan hasil belajar.

Terdapat beberapa kekurangan yang ada pada aktivitas guru dan anak, diantaranya:

- Penyampaian pendahuluan dalam kegiatan pembelajaraan kurang memfokuskan pada kondisi sekitar anak;

- Motivasi kepada siswa kurang dalam pembelajaran;

- Guru kurang intensif membimbing siswa yang kesulitan dalam mengungkapkan katakata saat bercerita didepan kelas;

- Guru perlu lebih banyak menyediakan waktu diskusi dengan siswa saat kegiatan bercerita. 


\section{Siklus II}

Pembelajaran pada siklus II diikuti oleh 33 anak kelompok A yang terdiri dari 18 anak perempuan dan 15 anak laki-laki.

a. Perencanaan ( Planning )

$\checkmark$ Perencanaan siklus II dilakukan menyiapkan perangkat pembelajaran terdiri atas penyusunan skenario pembelajaran yang tertuang dalam Rencana Program Pembelajaran Harian (RPPH) sesuai hasil refleksi siklus I;

$\checkmark$ Menyiapkan berbagai perlengkapan untuk membawa siswa ke halaman sekolah untuk mengamati berbagai tanaman yang ada dihalaman sekolah;

$\checkmark$ Membuat instrumen observasi/penilaian yang digunakan dalam siklus II.

b. Pelaksanaan Tindakan ( Action )

$\checkmark$ Kegiatan awal pembelajaran, guru menyampaikan pendahuluan meliputi penyampaian tujuan pembelajaran, yaitu anak mampu mendengarkan guru atau teman berbicara dan mampu menceritakan kembali hasil kegiatan yang telah dilakukan;

$\checkmark$ Kegiatan inti pembelajaran, guru menjelaskan kegiatan pembelajaran dengan menggunakan media lingkungan tanaman sambil mempraktekkan bagaimana cara menanam bunga mulai langkah awal sampai akhir, guru meminta kepada anak untuk mempraktekkan bagaimana cara menanam bunga mulai dari awal sampai akhir secara bergantian dengan siswa yang lain;

$\checkmark$ Kegiatan akhir pembelajaran, guru menyimpulkan hasil pembelajaran dan melakukan evaluasi dengan meminta anak untuk menceritakan kembali kegiatan yang telah dilakukan secara bergantian.

c. Observasi

Data hasil observasi dan evaluasi siklus II menunjukan bahwa dari 33 anak ternyata yang mempunyai kemampuan bercerita dalam setelah melakukan suatu kegiatan sesuai dengan standar ketuntasan belajar yang mencapai $>80 \%$, ada 29 anak yang tuntas belajar yaitu sebesar $87 \%$ dan masih belum bisa menceritakan kebali hasilkegiatannya dengan ada 4 siswa atau $13 \%$.

d. Refleksi

Berdasarkan hasil observasi menunjukkan adanya peningkatan kemampuan bercerita pada anak dengan menggunakan media lingkungan pada siklus II, hal ini terjadi karena:

$\checkmark$ Pengelolaan setiap kegiatan pembelajaran menunjukkan peningkatan;

$\checkmark$ Anak aktif menunjukkan peningkatan dalam bercerita; 
$\checkmark$ Kondisi yang melibatkan aktivitas anak dalam kegiatan pembelajaran menunjukkan peningkatan;

$\checkmark$ Melalui pemanfaatan media lingkungan kemampuan bercerita anak meningkat.

Penelitian tindakan kelas ini telah dilakukan secara bertahap. Pada kegiatan siklus I, proses tersebut menghasilkan kemampuan bercerita dengan menggunakan media lingkungan sebesar $36.4 \%$. Hasil tersebut belum mencapai standar ketuntasan belajar $>80 \%$, sehingga dilanjutkan pada kegiatan siklus II. Perencanaan tindakan pada siklus II bersumber dari masalah-masalah yang menghambat perkembangan kemampuan bercerita dengan media lingkungan pada siklus I.

Setelah diadakan perbaikan pembelajaran dan langkah-langkah tindakan aktivitas mengajar yang dilakukan oleh guru, berpengaruh sangat tinggi pada siklus II dan menunjukkan peningkatan kemampuan bercerita dengan media lingkungan yakni, anak yang tuntas belajar sebanyak 29 anak yang mencapai $87 \%$, dan sudah melebihi stndar ketuntasan belajar $>80 \%$, sehingga penelitian tindakan kelas ini tidak dilanjutkan lagi pada siklus berikutnya.

Peningkatan kemampuan anak dalam bercerita setelah diimplementasikannya media lingkungan dapat ditunjukan dalam Gambar 2. sebagai berikut:

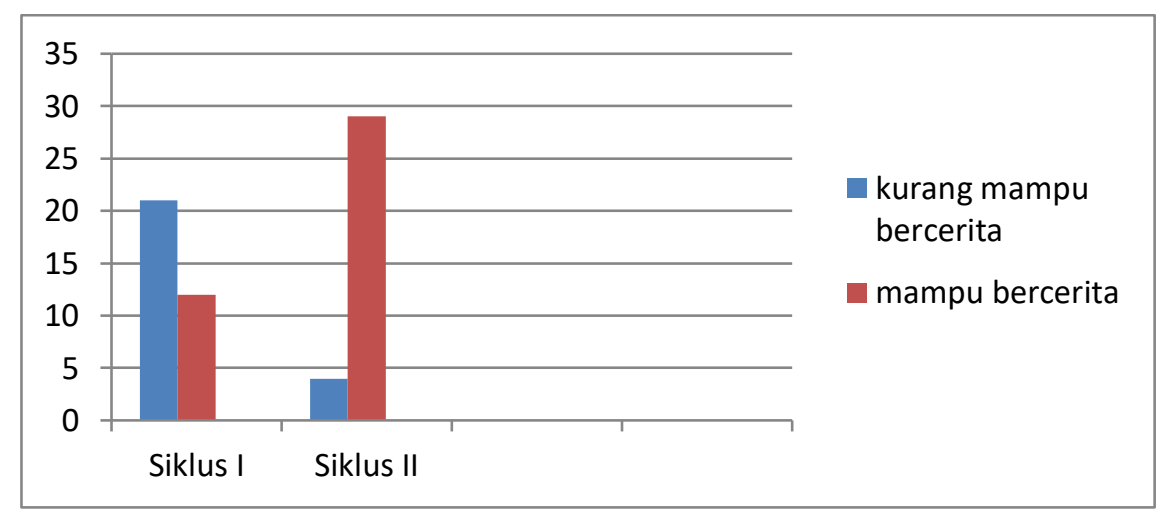

Gambar 2. Bagan peningkatan kemampuan bercerita pada anak

Anak usia dini berada dalam masa keemasan disepanjang rentang usia perkembangan manusia, penyataan ini didukung oleh pendapat dari Montessori (2004) yang mengatakan bahwa masa ini merupakan periode sensitif. Selama masa inilah anak secara khusus mudah menerima stimulus-stimulus dari lingkungannya. Pada masa ini anak siap melakukan berbagai kegiatan dalam rangka memahami dan menguasai lingkungannya.

Pada hakekatnya anak-anak adalah makhluk individu yang membangun sendiri pengetahuannya. Anak lahir dengan membawa sejuta potensi yang siap untuk ditumbuhkembangkan asalkan lingkungan menyiapkan situasi dan kondisi yang merangsang kemunculan dari potensi yang tersembunyi tersebut. 
Lima tahun pertama dalam kehidupan anak merupakan peletak dasar bagi perkembangan selanjutnya. Anak yang mengalami masa bahagia berarti terpenuhi segala kebutuhan fisik maupun psikis di awal perkembangan, diramalkan akan dapat melaksanakan tugas-tugas perkembangan selanjutnya. Ahmad Susanto (2011) juga mengatakan bahwa untuk meningkatkan perkembangan mental anak ke tahap yang lebih tinggi dapat dilakukan dengan memperkaya pengalaman anak terutama pengalaman kongkrit, karena dasar perkembangan mental adalah melalui pengalaman aktif dengan menggunakan benda-benda di sekitarnya.

Pada proses belajar mengajar kehadiran media mempunyai arti yang cukup penting. Pada kegiatan tersebut ketidakjelasan bahan yang disampaikan dapat dibantu dengan menghadirkan media sebagai perantara. Kerumitan bahan yang akan disampaikan kepada peserta didik dapat disederhanakan dengan bantuan media. Media dapat mewakili apa yang kurang mampu guru ucapkan melalui kata-kata atau kalimat tertentu. Dengan demikian, peserta didik lebih mudah mencerna bahan daripada tanpa bantuan media.

Penggunaan media pembelajaran menyebabkan materi pelajaran dapat disampaikan dengan baik. Jika media yang dibutuhkan tidak tersedia di sekolah maka guru bisa mengusahakan dengan memanfaatkan segala macam benda untuk dijadikan sebagai media tergantung dari kebutuhan. Media yang biasa dimanfaatkan seperti tumbuhan yang ada di sekitar kita. Proses pembelajaran terjadi ketika ada interaksi antara lingkungan diri sendiri dengan lingkungan luar.

Ada beberapa alasan yang mendukung pemanfaatan media sederhana dalam proses pembelajaran yaitu: Alasan pertama adalah penggunaan media yang sesuai dengan materi pelajaran dalam mengembangkan kemampuan bercerita anak dapat memberikan pengalaman baru dan mengubah prilaku (pengetahuan, nilai-nilai atau ketrampilan) melalui aktivitas kejiwaan sendiri. Oleh karena itu, sebagai seorang pendidik diharapkan mampu menciptakan media yang dibuat sendiri dengan memanfaatkan sumber belajar yang ada di lingkungan sekitar dengan harapan peserta didik dapat berimajinasi, perasaannya tersentuh dan terjadi pemahaman yang mendalam sehingga mampu memahami, mengingat, dan melakukan sesuatu yang diajarkan dengan baik. Misalnya, dalam proses pembelajaran guru bertanya jawab dengan menggunakan media yang dibuat maupun yang ada di sekitar. Agar proses pembelajaran lebih bermakna, maka peserta didik dapat terlibat langsung melalui proses bagaimana cara menanam bunga sampai selesai. Setelah anak mempraktekan bagaimana cara menanam bunga, anak diminta menceritakan dengan menggunakan bahasanya sendiri dengan memberi motivasi agar anak mau bercerita. 
Alasan kedua agar panca indra peserta didik dapat belajar secara optimal dalam proses belajar, panca indra perlu dirangsang, dilibatkan, dan digunakan sehingga mampu mengetahui, memahami, mengingat, menganalisis dan memperagakan kembali apa yang disampaikan guru dengan baik dan benar, secara kognitif, afektif, atau pun psikomotorik.

Alasan ketiga, penggunaan media sederhana mampu merangsang imajinasi peserta didik dan memberi kesan yang mendalam ketika digunakan secara seimbang dan sesuai dengan materi pelajaran.

Alasan keempat meskipun media pembelajaran sangat dibutuhkan dalam proses pembelajaran, tetapi media tersebut tidak akan efektif apabila digunakan semaunya. Dalam memilih media seorang pendidik harus tahu betul karakteristik peserta didik, usia, kondisi sosial ekonomi, tujuan pelajaran, cakupan materi dan faktor-faktor lain yang mempengaruhi keberhasilan pemanfaatan media lingkungan.

Bercerita dengan media akan lebih memudahkan siswa dalam berimajinasi tentang isi cerita, juga dapat menarik perhatian anak sehingga mendorong anak ikut serta dalam kegiatan bercerita. Pemanfaatan media lingkungan dapat meningkatkan kemampuan bercerita anak. Hal ini sesuai dengan pendapat Sudjana dan Rivai (1992) yang menyatakan bahwa dalam teknik penggunaan media lingkungan, siswa dituntut untuk menghayati objek tertentu dengan merekam apa yang dialami, dilihat, didengar, dan dirasakan selama kegiatan berlangsung.

Media lingkungan juga berperan dalam menemukan ide bercerita. Menurut Daryanto (2011), banyak ide di lingkungan sekitar manusia. Salah satu cara menemukan ide tersebut adalah menggunakan kepekaan indera, kemudian yang terpenting adalah memikirkan dan merenung hasil kepekaan indera tersebut. Berdasarkan hal-hal di atas, media lingkungan mempunyai peranan dalam menemukan bahan bercerita melalui pengalaman siswa. Pengalaman-pengalaman tersebut selanjutnya direnungkan, dipikirkan, dan dituangkan dalam rangkaian bercerita.

\section{SIMPULAN}

Berdasarkan hasil observasi dan analisis hasil observasi pada siklus I diperoleh data bahwa 22 siswa $(63,6 \%)$ masih belum bisa bercerita dengan baik dan 12 siswa $(36,4 \%)$ sudah mampu bercerita dengan baik. Data pada siklus I belum sesuai dengan KKM (>80\%), sehingga dilanjutkan ke siklus II. Berdasarkan hasil observasi dan analisis hasil observasi pada siklus II diperoleh bahwa 4 (13\%) siswa masih belum bisa bercerita dengan baik dan 29 siswa (87\%) sudah mampu bercerita dengan baik. Berdasarkan hasil tersebut dapat disimpulkan bahwa implementasi media lingkungan dapat meningkatkan kemampuan bercerita pada anak usia dini. 


\section{DAFTAR PUSTAKA}

Ahmad Susanto. (2011). Perkembangan Anak Usia Dini: Pengantar Dalam Berbagai Aspek. Jakarta: Kencana Prenadamedia Group.

Daryanto. (2011). Media Pembelajaran. Bandung: PT. Sarana Tutorial.

Legiman. (2015). Penelitian Tindakan Kelas (PTK). Widyaiswara LPM D.I.Yogyakarta. Kementrian Pendidikan dan Kebuyaan.

Mentessori. (2004). The Mentessori Method: The Origins on of Educational Innovation: Including Abridged and Annotated Edition on Maria Mentessori's The Mentessori Method. Lanham. Bulder.Newyork.Toronto.Oxford: Rowman \& littlefiel Publishers.INC.

Musfiroh,T. (2005). Bercerita UntukAnak Usia Dini. Jakarta:Depdiknas.

Oemar Hamalik. (1989). Media Pendidikan. Bandung: Citra Aditya.

Sujiono, Yuliana Nurani. (2009). Konsep Dasar Pendidikan Anak Usia Dini. Jakarta: PT Indeks.

Sudjana dan Rivai. (1992). Media Pembelajaran. Jakarta: PT. Raja Garfindo. Perasada

Sudjana, Ahmad Rivai. (2014). Pemanfaatan Media Dalam Pembelajaran. Bandung: PT Remaja Rosydakarya.

Undang-Undang RI Nomor 20. (2003). Sistem Pendidikan Nasional pasal 28 ayat 3 pasal 1 (butir4) tentang kebijakan PAUD. Jakarta : PT.Armas Duta Jaya 